\title{
Study on Growth and Root Yield of Radish (Raphanus sativus Lam.) as Influenced by Nutrition
}

\author{
Ahmad Fawad Satari*, V. Srinivasa, Devaraju, M. Shivaprasad and M. Ganapathi \\ Department of vegetable science, College of Horticulture, Mudigere, India \\ University of Agricultural and Horticultural Sciences, Shivamogga, Karnataka, India \\ *Corresponding author
}

\section{A B S T R A C T}

\begin{tabular}{|l|}
\hline Key w o r d s \\
Radish, Nutrition, \\
Root yield \\
\hline Article Info \\
\hline Accepted: \\
22 July 2020 \\
Available Online: \\
10 August 2020 \\
\hline
\end{tabular}

An experiment was conducted to find out the optimum nutrient levels of NPK on growth and yield of radish cv. Pusa Chetki in open field condition at department of Vegetable Science, College of Horticulture, Mudigere, during 2019-2020. The experiment consists of different levels of nutrition which were tried in various combinations and assessed for growth and yield parameters. Among the different nutrition levels, $\mathrm{T}_{4}(200: 100: 50 \mathrm{~kg}$ NPK / ha) recorded significantly maximum plant height $(42.71 \mathrm{~cm})$, number of leaves per plant (14.47), leaf length $(32.57 \mathrm{~cm})$, fresh weight of root $(271.33 \mathrm{~g})$, dry weight of root $(9.89 \mathrm{~g} /$ plant $)$, total chlorophyll content $(1.75 \mathrm{mg} / \mathrm{g}$ fr. wt), root length $(23.60 \mathrm{~cm})$, root girth $(13.13 \mathrm{~cm})$ as compared to control. The maximum root yield per plot $\left(5.00 \mathrm{~kg}\right.$ ) and per hectare $(33.33 \mathrm{t})$ was also recorded in $\mathrm{T}_{4}$ (200:100:50 kg NPK / ha).The above results revealed that application of 200 $\mathrm{kg}$ nitrogen, $100 \mathrm{~kg}$ phosphorus and $50 \mathrm{~kg}$ potassium per hectare was found to be optimum nutrition level for best growth and yield of radish under hill zone of Karnataka.

\section{Introduction}

Radish (Raphanus sativus L.) is one of the most popular root vegetable crops, which is cultivated for its enlarged edible roots. It is a quick growing and short duration vegetable crop suitable for growing both in temperate and tropical climate. Though Western Asia was considered as original home of radish, the variability existing among the cultivated forms in morphology and ecology signifies the multicenter origin of this crop. Wild species are available in Mediterranean region are considered probable progenitors of European radish. Japanese type would have originated from wild species that remain in coastal region of Japan.

Radish root is a good source of vitamin-C (ascorbic acid) containing 15-40 mg per $100 \mathrm{~g}$ of edible portion and supplies a variety of minerals. Trace elements in radish include 
aluminum, barium, lithium, manganese, silicon, titanium, fluorine and iodine. Tender leaves which are used as greens are rich in vitamin-A and C. Roots are also rich in carbohydrate and protein. Pinked skinned radish is generally richer in ascorbic acid than the white skinned one. The characteristic pungent flavor of radish is due to the presence of volatile isothiocynates (Bose et al., 2000).

It is well documented that growth and yield of plants are greatly influenced by application of wide range of nutrients (Gupta, 2001). According to Mohamed (1984), most of the farmers usually do not apply any fertilizer or just apply a small amount of urea or organic manures of unspecified quantity resulting in lower crop yield. Plants obtain nutrients from soil, besides water, different inorganic substances that are essential for the general metabolism of the plants. The supply and absorption of inorganic elements needed for growth and development is defined as nutrition, and these elements are called plant nutrients.

\section{Materials and Methods}

A field experiment was conducted at College of Horticulture, Mudigere during the period from November 2019 to December 2019. The experiment was designed to study the effect of nutrition on growth and yield of radish (Raphanus Sativus Lam.). The experiment was laid out in Randomized Complete Block Design (RCBD) with three replications. Size of each plot was $1.5 \times 1.0 \mathrm{~m}$. The experiment consists of ten different treatments nutrition levels, $\mathrm{T}_{1}-\left(50: 100: 50 \mathrm{~kg}\right.$ NPK / ha), $\mathrm{T}_{2}-$ (100:100:50 kg NPK / ha), $\mathrm{T}_{3}-(150: 100: 50$ $\mathrm{kg} \mathrm{NPK} / \mathrm{ha}), \mathrm{T}_{4}-(200: 100: 50 \mathrm{~kg} \mathrm{NPK} / \mathrm{ha})$, $\mathrm{T}_{5}-(50: 150: 50 \mathrm{~kg}$ NPK / ha $), \mathrm{T}_{6}-$ (50:200:50 kg NPK / ha), $\mathrm{T}_{7}-(50: 250: 50 \mathrm{~kg}$ NPK / ha), $\mathrm{T}_{8}-\left(50: 100: 100 \mathrm{~kg}\right.$ NPK / ha), $\mathrm{T}_{9}$ - (50:100:150 kg NPK / ha), $\mathrm{T}_{10}$ (50:100:200 kg NPK / ha). The crop was fertilized with different levels of nitrogen, phosphorus and potassium for each plot in every replication in the form of urea, single super phosphate and murate of potash respectively. Entire SSP, MOP and 50 per cent urea was applied as a basal dose at the time of sowing and remaining 50 per cent nitrogen applied 20 days after sowing. The package of practice recommendation of fertilizer (50: 100: $50 \mathrm{~kg}$ NPK ha ${ }^{-1}$ ) was included in the study for comparison. Various observations related to the growth and yield of the radish were recorded at periodic growth intervals. Five plants per plot were selected randomly and tagged for recording various growth and yield parameters.

\section{Results and Discussion}

The plant height, number of leaves per plant, leaf length and total chlorophyll content were found significant difference with different nutrition levels (Table 1). The results showed that significantly maximum plant height, number of leaves per plant, leaf length and total chlorophyll content $(42.71 \mathrm{~cm}, 14.47$, $32.57 \mathrm{~cm}$ and $1.75 \mathrm{mg} / \mathrm{g}$, respectively) was recorded in $\mathrm{T}_{4}$ (200:100:50 $\mathrm{kg}$ NPK / ha) followed by T3 (150:100:50 kg NPK / ha). While, minimum was recorded in $\mathrm{T} 1$ (50:100:50 kg NPK / ha). The positive influence of the nutrients on plant height clearly supports the fact that higher application of nitrogen has a vital role in betterment of plant physiological process such as cell division, cell elongation along with timely metabolic processes and also favoured the greater assimilation of photosynthates. These results are in conformity with the findings of Tripathi et al., (2017) and Baloch et al., (2014) in radish. The increase in number of leaves per plant could be attributed to the enhanced availability of nutrients at the appropriate time, which might have resulted in increased photosynthetic rate and accumulation of metabolites in plants. These 
results are in line with the observations made by Lakra et al., (2017) and Dash et al., (2018) in radish. The increase in leaf length may be due to increased availability of higher dose of nutrients. Similar results have been reported by Thapa et al., (2003) and Jadhav et al., (2014) in radish. The increase in chlorophyll content could be attributed to increased $\mathrm{N}$ content in the leaves, which is a constituent of chlorophyll pigment. The increase in $\mathrm{N}$ content of the leaves is due to the better uptake of nitrogen. Similar results have been quoted by Koodi et al., (2017) and Sharavati et al., (2018) in sweet potato.

The fresh and dry weight of root, root length and root girth was significantly influenced by different nutrition levels (Table 2). The fresh and dry weight of root varied significantly among different nutrition levels. The results indicated that maximum fresh and dry weight of root (271.33 and $9.89 \mathrm{~g}$ ) was recorded in $\mathrm{T}_{4}$ (200:100:50 kg NPK / ha). While, minimum fresh and dry weight of root (110.67 and 4.92 g) was recorded in T1 (50:100:50 kg NPK / ha). The increase in fresh and dry weight of root could be due to higher uptake and accumulation of greater amount of photosynthates leading to increase in number of leaves, plant size and fresh bio mass, which in turn yields higher dry matter content. Similar results have been quoted by (Baloch et al., 2014) and Kiran et al., (2016) in radish. The root length and girth varied significantly among different nutrition levels.

Table.1 Effect of nutrition on morphological characters in radish

\begin{tabular}{|c|c|c|c|c|}
\hline Treatments & $\begin{array}{c}\text { Plant height } \\
(\mathrm{cm})\end{array}$ & $\begin{array}{l}\text { Number } \\
\text { of leaves } \\
\text { per plant }\end{array}$ & $\begin{array}{l}\text { Leaf length } \\
(\mathrm{cm})\end{array}$ & $\begin{array}{l}\text { Total chlorophyll } \\
\text { content (mg / g) }\end{array}$ \\
\hline$T_{1} \quad-50: 100: 50 \mathrm{~kg} \mathrm{NPK} / \mathrm{ha}$ (Control) & 33.13 & 9.87 & 25.24 & 0.74 \\
\hline $\mathrm{T}_{2}-100: 100: 50 \mathrm{~kg} \mathrm{NPK} / \mathrm{ha}$ & 36.30 & 11.93 & 28.97 & 1.14 \\
\hline$T_{3}-150: 100: 50 \mathrm{~kg} \mathrm{NPK} / \mathrm{ha}$ & 39.27 & 13.27 & 31.00 & 1.60 \\
\hline $\mathrm{T}_{4}-200: 100: 50 \mathrm{~kg} \mathrm{NPK} / \mathrm{ha}$ & 42.71 & 14.47 & 32.57 & 1.75 \\
\hline$T_{5}-50: 150: 50 \mathrm{~kg}$ NPK / ha & 34.38 & 11.47 & 27.44 & 0.85 \\
\hline$T_{6}-50: 200: 50 \mathrm{~kg}$ NPK / ha & 36.88 & 12.47 & 29.83 & 1.30 \\
\hline 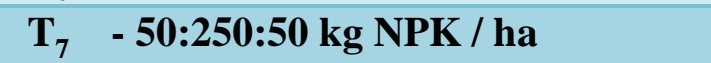 & 34.43 & 11.07 & 26.43 & 1.02 \\
\hline $\mathrm{T}_{8}-50: 100: 100 \mathrm{~kg} \mathrm{NPK} / \mathrm{ha}$ & 35.80 & 11.20 & 28.55 & 1.01 \\
\hline$T_{9}-50: 100: 150 \mathrm{~kg}$ NPK / ha & 35.00 & 11.30 & 26.26 & 0.83 \\
\hline$T_{10}-50: 100: 200 \mathrm{~kg}$ NPK / ha & 35.03 & 11.13 & 26.86 & 0.90 \\
\hline S.Em \pm & 0.78 & 0.18 & 0.90 & 0.11 \\
\hline C.D@ 5\% & 2.31 & 0.54 & 2.67 & 0.34 \\
\hline
\end{tabular}


Table.2 Effect of nutrition on root parameters in radish

\begin{tabular}{|c|c|c|c|c|}
\hline Treatments & $\begin{array}{l}\text { Fresh wt of } \\
\text { root }(\mathrm{g})\end{array}$ & $\begin{array}{c}\text { Dry wt of } \\
\text { root }(g)\end{array}$ & $\begin{array}{l}\text { Root length } \\
\text { (cm) }\end{array}$ & $\begin{array}{l}\text { Root girth } \\
\text { (cm) }\end{array}$ \\
\hline$T_{1}-50: 100: 50 \mathrm{~kg}$ NPK / ha (Control) & 110.67 & 4.92 & 15.98 & 7.22 \\
\hline$T_{2}-100: 100: 50 \mathrm{~kg} \mathrm{NPK} / \mathrm{ha}$ & 179.67 & 6.89 & 19.47 & 10.14 \\
\hline$T_{3}-150: 100: 50 \mathrm{~kg}$ NPK / ha & 235.33 & 8.73 & 21.57 & 11.83 \\
\hline$T_{4}-200: 100: 50 \mathrm{~kg} \mathrm{NPK} / \mathrm{ha}$ & 271.33 & 9.89 & 23.60 & 13.13 \\
\hline$T_{5}-50: 150: 50 \mathrm{~kg} \mathrm{NPK} / \mathrm{ha}$ & 174.67 & 6.14 & 19.21 & 9.58 \\
\hline$T_{6}-50: 200: 50 \mathrm{~kg} \mathrm{NPK} / \mathrm{ha}$ & 205.00 & 7.65 & 20.90 & 11.18 \\
\hline$T_{7} \quad-50: 250: 50 \mathrm{~kg} \mathrm{NPK} / \mathrm{ha}$ & 160.33 & 5.86 & 18.17 & 8.95 \\
\hline$T_{8}-50: 100: 100 \mathrm{~kg} \mathrm{NPK} / \mathrm{ha}$ & 143.67 & 6.08 & 17.93 & 9.22 \\
\hline$T_{9}-50: 100: 150 \mathrm{~kg} \mathrm{NPK} / \mathrm{ha}$ & 136.00 & 5.62 & 17.94 & 8.17 \\
\hline$T_{10}-50: 100: 200 \mathrm{~kg} \mathrm{NPK} / \mathrm{ha}$ & 173.67 & 6.56 & 18.37 & 8.73 \\
\hline S.Em \pm & 10.16 & 0.41 & 0.56 & 0.25 \\
\hline C.D@ $@$ 5\% & 30.17 & 1.21 & 1.66 & 0.74 \\
\hline
\end{tabular}

Fig.1 Root yield per plot and per hectare as influenced by nutrition in radish

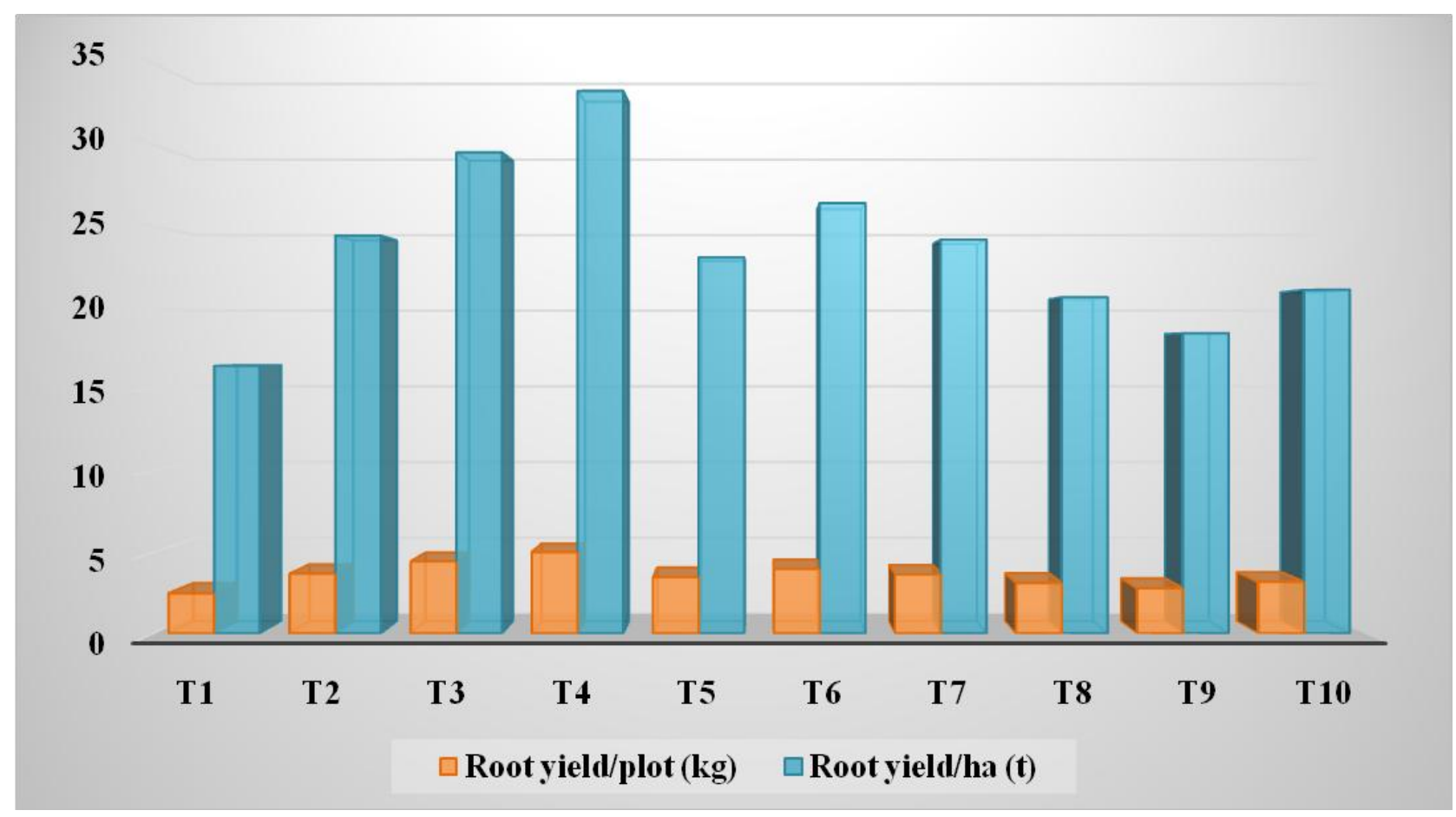

The results indicated that maximum root length and root girth $(23.60 \mathrm{~cm}$ and $13.13 \mathrm{~cm}$, respectively) were recorded in $\mathrm{T}_{4}$ (200:100:50 $\mathrm{kg}$ NPK / ha). While, minimum root length and root girth $(15.98 \mathrm{~cm}$ and $7.22 \mathrm{~cm}$, respectively) were recorded in T1 (50:100:50 $\mathrm{kg}$ NPK / ha). The significant effect of potassium on root characters might be due to the fact that easily available potassium plays an important role in starch formation and 
metabolism and thereby increased the length and girth of root. These findings are in close conformity with those reported by Kumar et al., (1994) and Ijaz et al., (1997) in radish.

Among the different nutrition treatments, $\mathrm{T}_{4}$ recorded the significantly maximum root yield per plot and per hectare $(5.00 \mathrm{~kg} / \mathrm{plot}$ and $33.33 \mathrm{t} / \mathrm{ha}$, respectively) followed by $\mathrm{T}_{3}$ (4.43 kg / plot and $29.55 \mathrm{t} / \mathrm{ha}$, respectively). While the lowest root yield per plot and per hectare $(2.47 \mathrm{~kg} \mathrm{/} \mathrm{plot} \mathrm{and} 16.44 \mathrm{t} / \mathrm{ha}$, respectively) was observed in $\mathrm{T}_{1}$ (50:100:50 $\mathrm{kg} \mathrm{NPK} \mathrm{/} \mathrm{ha)} \mathrm{nutrition} \mathrm{level.} \mathrm{Potassium} \mathrm{is}$ thought to be essential for the formation and translocation of carbohydrates and needed in large quantities by most of the root crops (Thompson and Kelly, 1957). Potassium imparts resistance to plant against pests, diseases and drought condition, which might have been resulted in heavy growth of the crop. Favorable effects of potassium application on growth and yield attributes were responsible for higher root yield. Similar results have been quoted by Srinivas and Naik (1990), Parthasarathi et al., (1999), Ndang and Akali (1999) and Bokhtiar et al., (2001) in radish.

The result and discussion of this study concluded that the application $\mathrm{T}_{4}$ (200:100:50 $\mathrm{kg}$ NPK / ha) nutrition level recorded maximum with respect to growth and yield parameters of radish.

\section{Acknowledgement}

I am thankful to the HOD, Department of Vegetable Science, $\mathrm{COH}$, Mudigere, Chikkamagaluru (Karnataka) for all the facilities provided for conducting my research.

\section{References}

Baloch, P. A. Uddin, R. and Nizamani, F. K. 2014 Effect of nitrogen, phosphorus and potassium fertilizers on growth and yield characteristics of radish (Raphinus sativus L.). J. Agric. Environ. Sci, 14(6):565-569.

Bokhtiar, S. M. Karim, A. J. M. S. Hossain, K. M. Hossain, T. and Egashira, K. 2001. Response of radish to varying levels of irrigation water and fertilizer potassium on clay terrace soil of Bangladesh. Communications in Soil Sci. and Plant Analysis, 32(17/18): 2979-2991.

Bose, T. K. Kabir, J. Das, P. and Joy, P. P. 2000, Tropical Horticulture, Volume-1 Naya Prokash, Calcuta. Pp. 145.

Dash, S. K. Pathak, M. Tripathy, L. and Barik, S. 2018. Studies on effect of integrated nutrient management on growth and yield attributes in radish (Raphanus sativus L.) and its residual effect in coriander (Coriandrum Sativum L.) in radish-coriander cropping sequence J. Pharmacognosy and Phytochemistry, 8(1):319-322.

Ijaz, H. Ihsanul, H. Mohammad, S. and Asif, R. 1997. Effect of nitrogen alone and in combination with constant doses of phosphorus and potassium on yield of radish. Sarhad J. Agri, 13(1): 39-43.

Jadhav, P. B. Patel, D. J. Kireeti, A. Patil, N. B. Dekhane, S. S. Harad, N. B. and Jadhav, K. P. 2014. Effect of different levels of vermicompost on growth and yield of radish $\mathrm{Cv}$. Local Variety. Int. J. Information Res. Rev, 1(2):029-031.

Kiran, M. Jilani, M. S. Waseem, K. and Sohail, M. 2016. Effect of organic manures and inorganic fertilizers on growth and yield of radish (Raphanus sativusL). Pak. J. Agric. Res, 29(4):363372.

Koodi, S., Singh, S. P., Kumar, M. R., Gathala, S. and Choudhary, R. 2017. Effect of NPK, FYM and vermicompost on growth, yield and quality of sweet potato. Chemical Science Review and 
Letters, 6(21): 495-499.

Kumar, P.B. Acharya, P.K. Dora, D.K. and Behera, T.K. 1994. Effect of graded levels of nitrogen and potassium on seed production of radish (Raphanus sativus L.) cv. Pusa chetki. Orissa J. Hort, 22(1/2): 36-40.

Lakra, A. Singh, D. Prasad, V. M. Deepanshu and Shabi, M. 2017. Effect of nitrogen and phosphorus on growth and yield of radish (Raphanus sativusL.) Cv. Pusha Chetki under shade net condition. The Pharma Innovation J, 6(11):768-770.

Mohamed, M. 1984. Effects of bed preparation and nitrogen fertilization on growth yield and quality of sweet potato (Ipomoea batatas). Acta Hort, 143:311318.

Ndang, Z. and Akali, S. 1999. Effect of nitrogen and potassium on growth and yield of radish. Indian Journal of Hill Farming, 12(1/2): 84-87.

Parthasarathi, K.S. Krishnappa, M. Chandre, G. Reddy, N.S. and Anjanappa, M. 1999. Growth and yield of certain radish to varying levels of fertility.
Karnataka J. Agri. Sci, 12(1/4): 148153.

Sharavati, M. B., Srinivasa, V., Devaraju, Bhagwath, A. R. and Shubha, A. S. 2018. Evaluation of sweet potato (Ipomoea batatas (L.) Lam) genotypes under hill zone of Karnataka.

Srinivas, K. and Naik, L.B. 1990. Growth and yield of radish (Raphanus sativus L.) in relation to nitrogen and potash fertilization. Indian J. Hort, 47(1):114119.

Thapa, U. Mohanto, B. Chattopadhyay, S.B. and Ghanti, P. 2003. Growth and yield of some cultivars of radish (Raphanus sativus L.) with nitrogen levels. Env. \& Eco, 21(4): 836-838.

Thompson, H.C and Kelly, W.C. 1957. Vegetable Crops, McGraw Hill Book Co, New York, pp.327-335.

Tripathi, A. K. Ram, R. B. Rout, S. Kumar, A. and Patra, S. S. 2017. Studies on the effect of nitrogen levels and spacing on quality traits of radish (Raphanus ativus L.) Cv. Kashi Sweta. Int. J. Chem. Stud, 5(6):537-540.

\section{How to cite this article:}

Ahmad Fawad Satari, V. Srinivasa, Devaraju, M. Shivaprasad and Ganapathi, M. 2020. Study on Growth and Root Yield of Radish (Raphanus sativus Lam.) as Influenced by Nutrition. Int.J.Curr.Microbiol.App.Sci. 9(08): 2466-2471. doi: https://doi.org/10.20546/ijcmas.2020.908.281 